\title{
Kukorica csíkos mozaik vírus (MDMV) populáció jellemzése két kukoricatermesztố területen
}

\author{
GELL GYÖNGYVÉR- PETRIK KATHRIN-SEBESTYÉN ENDRE-BALÁZS ERVIN \\ MTA Mezőgazdasági Kutatóintézete, Martonvásár
}

\begin{abstract}
Összefoglalás
A potyvírusok családjába tartozó kukorica csíkos mozaik vírus (Maize dwarf mosaic virus, MDMV) az egyszikú növények egyik legjelentôsebb kórokozója. Az MDMV genetikai állományának nagyfokú változékonysága és ennek lehetséges patológiai következményei figyelmünket a vírus tüneti determinánsainak és populációjának részletesebb elemzésére irányította. Vizsgálataink a köpenyfehérjét (CP- coat protein) kódoló régió összehasonlító analízisére terjednek ki.

Mintáinkat négy egymást követő évben (2006-2009) két, földrajzilag jól elkülönülő területrôl, a szegedi Gabonatermesztési Kht. tenyészkertjéból kukoricáról (Zea mays L. convar. saccharata), fenyércirokról (Sorghum halepense (L.) Pers) és szemes cirokról (Sorghum bicolor (L.) Moench), valamint martonvásári tenyészparcellákról gyújtöttük. A polimeráz láncreakció (PCR) módszerrel felszaporított köpenyfehérje gének nukleinsav sorrendjét meghatároztuk, majd feltérképeztük a vírus molekuláris rokonsági körét. Az izolátumok közti eltérés 0-13,6\%-ig terjed, attól függôen, hogy a köpenyfehérje gén N-terminális, központi- illetve C-terminális régióját vizsgáltuk. Az összesen nyolcvanhat MDMV izolátum közül öt esetben (Mv0702, Mv0801, Mv0811, Mv0814 és Mv0905) találtunk a köpenyfehérje N-terminális régiójában 13 aminosav hosszúságú inszerciót, ezek az izolátumok az adatbázisban megtalálható Argentin és Spanyol izolátumokkal egy külön csoportot alkotnak. A kapott eredmények azt igazolják, hogy az izolátumok a mintagyújtés évétôl és földrajzi helyétől függetlenül oszlanak el a törzsfán, a populáció stabil.
\end{abstract}

Kulcsszavak: MDMV, populáció, CP, inszerció 


\title{
Characterisation of a maize dwarf mosaic virus (MDMV) population on two maize production areas
}

\author{
GY. GELL-K. PETRIK-E. SEBESTYÉN-E. BALÁZS \\ Agricultural Research Institute of the Hungarian Academy of Sciences, Martonvásár
}

\begin{abstract}
Summary
The maize dwarf mosaic virus (MDMV) - a common potyvirus - is one of the most important pathogens of monocot plants. The high variability in the genetics of MDMV and its possible pathologic consequences drew our attention to the more detailed analysis of the symptomatic determinants of the virus and its population. Our examinations covered the comparative analysis of the coat protein coding region.

We collected our samples in four consecutive years on two geographically well separated areas. The maize (Zea mays L. convar. saccharata), Johnson grass (Sorghum halepense (L.) Pers) and sorghum (Sorghum bicolor (L.) Moench) samples were collected on the breeding plot of the company Cereal Research Non-Profit LTD. in Szeged, whereas other samples were collected on the breeding plot in Martonvásár. We determined the nucleic acid primary structure of the coat protein genes multiplied with the polymerase chain reaction (PCR) method, whereas the molecular relations of the virus was also determined. The difference between the isolates ranges from 0 to $13.6 \%$, depending on whether the $\mathrm{N}$-terminal, central, or the $\mathrm{C}$-terminal regions of the coat protein gene are observed. In 5 out of 86 MDMV isolates (Mv0702, Mv0801, Mv0811, Mv0814 and Mv0905), we found 13 amino-acid long insertions in the $\mathrm{N}$-terminal region of the coat protein. These isolates form a separate group together with the Argentine and Spanish isolates that can also be found in the database. The results show that the isolates are distributed in the taxonomic chart independently of the year and geographical location of the sample collection, therefore, the population is stable.
\end{abstract}

Key words: MDMV, population, CP, insertion 


\section{Bevezetés}

A Potyviridae családba tartozó kukorica csíkos mozaik vírus (Maize dwarf mosaic virus, MDMV) előfordulását először a hatvanas években regisztrálták az Egyesült Államokban (Janson és Ellett 1963, Williams és Alexander 1965), majd hamarosan hazánkban is leírták (Szirmai és Paizsné 1963). Gazdanövényei a kukorica, fenyércirok, köles, cirok fajok, valamint egyéb pázsitfú félék (Williams és Alexander 1965). Az MDMV maggal, mechanikai úton, valamint levéltetvekkel nem perzisztens módon terjed (Toler 1985).

A vírusfertőzésre a különböző kukoricafajták eltérő érzékenységet mutatnak, általánosan megfigyelhetô a mozaik tünetek kialakulása, törpülés, gyengén fejlett címer és rosszul kötött termés. A vírusfertôzés által okozott terméskiesés elérheti a 42\%-ot is (Peti 1983, Sum et al. 1979, Szirmai 1968). Figyelembe véve, hogy a fertőzöttség mértéke fajtánként akár $80 \%$ is lehet (Tóbiás et al. 2003), az MDMV kártétele gazdasági szempontból igen jelentôs. A gazdasági kártétel az abortált végű csövek nagy számából, a csövek méretének csökkenéséből és az ezerszemtömeg csökkenésébôl adódik össze (Toldiné 2008).

A vírus elleni védekezés legegyszerúbb módjai a megfelelô termesztési technológia, az MDMV-t terjesztô rovarvektorok (Myzus persicae (S.), Rhopalosiphum maidis (F.), Schizaphis graminum (R.) populációjának gyérítése, illetve a vírusrezervoárként szolgáló egyszikú gyomok (fenyércirok, Sorghum halepense L. Pers) irtása. Az MDMV elleni védekezés másik lehetséges módja toleráns illetve rezisztens kukoricafajták kialakítása. Klasszikus nemesítési folyamat esetében a rezisztencia leggyakoribb, de nem kizárólagos forrása a kukorica genomjában természetesen is megtalálható $M d m 1$ gén, amely a hatodik kromoszóma rövid karján, az endospermium színét meghatározó Y1 lokuszhoz kapcsoltan helyezkedik el (Scott és Louie 1996, Simcox et al. 1995). Vírus elleni rezisztencia elérhetô molekuláris nemesítési módszerekkel is, ilyenkor a vírus köpenyfehérjéjét kódoló gént (coat protein, CP), vagy annak egy szakaszát építik be a növény genomjába. Ez az úgynevezett kórokozó alapú rezisztencia (pathogen-derived resistance, PDR) sikerrel alkalmazható az MDMV esetében is, sôt az MDMV-B (SCMV) köpenyfehérjét termelô növény nem csak az SCMV, hanem MDMV, valamint az MDMV-MCMV (Maize chlorotic mottle virus) kevert fertôzéssel szemben is ellenállóvá vált (Murry et al. 1993). Magyarország Európa negyedik legnagyobb kukoricater- 
melője, hazánkban is komoly erőfeszítések folynak mind a vírus kártételének és a védekezés lehetőségeinek kutatása, mind a rezisztens kukoricafajták nemesítése terén (Gáborjányi et al. 1992, Hoang és Gáborjányi 1991, Milinkó 1977, Milinkó et al. 1979, Kovács et al. 1998, Kovács et al. 1994, Tóbiás és Palkovics 2004).

Az MDMV a trópusi fúféléket fertőzô potyvírusok csoportjába tartozik (Shukla et al. 1989). Ezen egymással szerológiailag rokon vírusok közé tartozik a cukornád mozaik vírus (Sugarcane mosaic virus, SCMV), a fenyércirok mozaik vírus (Johnsongrass mosaic virus, JGMV), a cirok mozaik vírus (Sorghum mosaic virus, SrMV), az MDMV, valamint a közelmúltban, Izraelben azonosított kukorica mozaik vírus is (Zea mosaic virus, ZeMV) (Seifers et al. 2000). A növényi vírusok többségéhez hasonlóan az MDMV örökítő anyaga egyszálú, pozitív orientációjú RNS, amely tíz fehérjét kódol. A mintegy 9,5kb hosszúságú, egyetlen ribonukleinsavból álló vírusgenom szervezôdése követi a potyvírusok általános felépítését. A vírus RNS 5' végéhez kovalensen kapcsolódó fehérje (VPg) feltehetôen az eukarióta mRNS-eken meglévô diguanozin sapkát helyettesíti, ezáltal segít a vírus RNS transzlációjának elindításában (Andino et al. 1999), az RNS 3' végén poliadenilált régió található. A vírus genetikai állománya egyetlen hosszú fehérjét (poliprotein) kódol, mely elôször autoproteolízissel, a proteáz aktivitású P1, HC-Pro és NIa fehérjék által hasad funkcióképes fehérjékké (Kong és Steinbiss 1998, Urcuqui-Inchima et al. 2001). A több funkciót is ellátó fehérjék közül a köpenyfehérje konzervált központi szakasza fôleg az enkapszidációban vesz részt, a változékonyabb aminosav sorrendú N-és C-terminális doméneknek a vírus rövid és hosszú távú mozgásában van szerepe (Dolja et al. 1994). Az N-terminális doménben található a levéltetûvel való átvihetôségért felelős DAG aminosav-motívum (Harrison és Robinson 1988, Pirone és Blanc 1996). A köpenyfehérje számos funkciói között szerepel még a vírusreplikáció szabályozása, valamint a gazdafaktorokkal való kapcsolata révén a vírus egyik fontos tüneti és gazdaspecifitás determinánsa (Riechmann 1992, Hong et al. 1995, Hajimorad et al. 2003).

A potyvírusok genetikai állománya - más RNS vírusokéhoz hasonlóan rendkívül változékony, a vírusgenom evolúciójában és az új gazdanövényekhez való adaptációjában központi szerepet játszanak a mutációs, illetve az intra-és intermolekuláris átrendezôdési (rekombinációs) folyamatok (Tomimura et al. 2003). A genetikai állomány ezen plasztikussága lehetôvé teszi az MDMV-vel szemben ellenálló kukoricafajták rezisztenciájának áttörését. Tóbiás és Palko- 
vics (2004) számolt be az MDMV-toleráns 'Dallas' fajtán megjelenô, az MDMV tüneteit mutató vírusbetegségről, melyrôl szerológiai és molekuláris biológiai vizsgálatok során bebizonyosodott, hogy a kórokozó a kukorica csíkos mozaik vírus volt (Tóbiás és Palkovics 2004, Tóbiás et al. 2003). Az izolátum köpenyfehérje régiójának nukleotid sorrendjét meghatározták, ebből következtettek a CP aminosav sorrendjére. Arra a meglepó eredményre jutottak, hogy a 'Dallas' fajtáról izolált vírus köpenyfehérjéje az N-terminális szakaszon 13 aminosavból álló inszerciót hordoz, mely feltehetôen hozzájárult a toleráns fajta sikeres fertôzéséhez.

\section{Anyag és módszer}

Mintáinkat négy egymást követő évben (2006-2009), két földrajzilag jól elkülönülő területről, a szegedi Gabonatermesztési Kht. tenyészkertjéből kukoricáról (Zea mays L. convar. saccharata), fenyércirokról (Sorghum halepense (L.) Pers) és szemes cirokról (Sorghum bicolor (L.) Moench), valamint martonvásári tenyészparcellákról gyújtöttük.

A tüneteket mutató levélmintákat 0,02 M foszfát-pufferben (pH 8) homogenizáltuk, celittel elkevertük és a kapott présnedvvel a növényeket bedörzsöltük. Korábbi irodalmi adatok alapján (Kovács et al. 1997) 2-3 leveles fejlettségi stádiumban lévő csemegekukoricát (Zea mays L. convar. saccharata 'Honey') használtunk inokuláláshoz. A levélmintákat további feldolgozásig -70 ${ }^{\circ} \mathrm{C}$-on RNAlater oldatban (Ambion) tároltuk.

A levelekbő́l Qiagen RNeasy Plant Mini Kittel RNS-t vontunk ki. A kinyert RNS minôségét gél-elektroforézissel ellenôriztük, mennyiségét pedig spektrofotometrikus úton határoztuk meg, majd a Fermentas cég RevertAid First Strand cDNA Synthesis kitjével oligo $\mathrm{dT}_{18}$ nukleotid primerrel reverz transzkripciót végeztünk. A reakcióelegyet a gyártó ajánlása szerint állítottuk össze.

Az egyszálú cDNS-ból a PCR primer pár (MDMV 8198 fwd 5' AAA CCG GTG GYT RCT YGA ART GC 3'; MDMV3'- 5' ATC CTA GGT TTT TTT TTT TTT TTT TTT TTT TTT TTT GTC 3' ) a 3' nem kódoló régiót, a köpenyfehérjét kódoló régiót és az NIb mintegy 323 bp hosszúságú szakaszát szaporította fel ( 1317 bp).

A PCR-rel felszaporított és gélból visszaizolált DNS fragmentumokat pLitmus28i (2823 bp, New England BioLabs) vektor AgeI-XmaJI klónozó helyére illesztettük be. A ligátumokat Escherichia coli TOP10 (Invitrogen) kompetens 
sejtekbe transzformáltuk, majd kék-fehér szelekcióval választottuk ki az inszertet tartalmazó klónokat. A valóban pozitívnak bizonyult minták bázissorrendjét meghatároztuk.

A nukleinsav, illetve az in silico következtetett CP aminosav szekvencia adatokból ClustalX és NJplot programokkal elkészítettük a rokonságot jellemzô törzsfát.

Az MDMV rokonsági körének átlagos diverzitását és genetikai távolságát (p-distance) MEGA 4.0.2 programmal számítottuk ki (Kumar et al. 2008).

\section{Eredmények és megvitatásuk}

A szántóföldrôl gyưjtött, különbözô tüneteket mutató kukorica levélminták nedvével inokulált csemegekukoricán (Zea mays L. convar. saccharata, „Honey”) nem mutatkoztak eltérô tünetek, ebból arra következtethetünk, hogy MDMV esetében inkább a gazdanövény felelôs a különbözô tünetek kialakításáért, mint a vírus köpenyfehérje génjének apróbb eltérései vagy a földrajzi elhelyezkedés.

A négy év során gyưjtött mintáinkból összesen nyolcvanhat esetben (1. táblázat) sikerült az MDMV jelenlétét kimutatni PCR módszer segítségével.

1. táblázat. 2006-2009 idôszakban gyüjtött MDMV izolátumok

\begin{tabular}{lcccc}
\hline & $\begin{array}{c}\text { Gyújtött minták } \\
\text { száma } \\
\text { Martonvásár }\end{array}$ & MDMV+ & $\begin{array}{c}\text { Gyújtött minták } \\
\text { száma } \\
\text { Szeged } \\
(1)\end{array}$ & MDMV+ \\
\hline 2006 & 21 & 4 & 12 & 12 \\
2007 & 12 & 7 & 10 & 10 \\
2008 & 17 & 17 & 15 & 15 \\
2009 & 12 & 12 & 10 & 9 \\
Összesen (3) & & 40 & & 46 \\
\hline
\end{tabular}

Table 1. MDMV isolates collected from 2006 to 2009. Samples were MDMV positive in 86 cases. (1) Number of collected samples, Martonvásár, (2) Number of collected samples, Szeged, (3) Total.

A nukleinsav, illetve az in silico következtetett CP aminosav szekvencia adataiból elkészítettük a rokonsági viszonyokat ábrázoló törzsfát, amely össze- 
sen kilencvenkét MDMV izolátum szekvenciáját tartalmazza, ebbôl hat az NCBI génbank adatbázisból származott (http://www.ncbi.nlm.nih.gov/). Ezen szekvenciák és regisztrációs számaik a következők: MDMV-Hungary-ScH/SYN (AJ542536), MDMV-Spain-M (AM110758), MDMV-Spain-Sp (AJ416645), MDMV-A (U07216) MDMV-Argentina-Arg (DQ973169) és MDMV-BulgarianBul (NC003377).

A hazai izolátumok és a számítógépes adatbázisban megtalálható CP szekvenciák összehasonlításával rokonsági törzsfát készítettünk (Gell et al. 2008, Gell et al. 2010), mely alapján megállapítható, hogy sem földrajzi elhelyezkedés, sem pedig évjárat alapján nem találhatók szekvencia variánsok, a víruspopulációk stabilnak tekinthetôk.

Kivételt képez néhány martonvásári izolátum (Mv0702, Mv0801, Mv0811, Mv0814, Mv0905), melyek köpenyfehérjéjük N-terminális részén hordoznak 13 aminosav hosszúságú inszerciót. Az egyik martonvásári izolátumnál, melyet 2008-ban fenyércirokról gyưjiöttünk, az inszerció előtt 9 aminosav hosszúságú delécióval is rendelkezik (1. ábra).

\section{1. ábra. Inszerciót tartalmazó MDMV izolátumok köpenyfehérje} amino terminális régiójának összehasonlitása

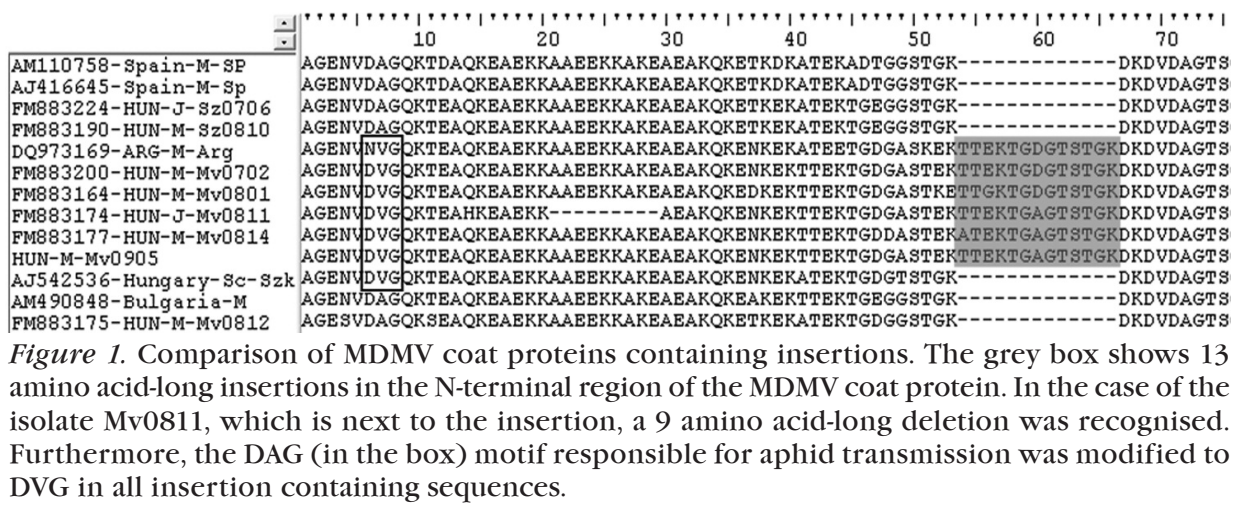

Az összehasonlító számítógépes vizsgálatok alapján az izolátumok egy részében talált inszert nagyfokú konzerváltságot mutat mind a nukleinsav bázissorrendjét, mind elhelyezkedését tekintve. További számítógépes analízis alapján arra a következtetésre jutottunk, hogy az inszerció szerepet játszik a vírus RNS stabilitásában (Petrik et al. 2010). 
Az inszerciót tartalmazó izolátumok az adatbázisban megtalálható Argentin izolátummal külön csoportot alkotnak a rokonsági törzsfán. További érdekesség, hogy az összes inszerciót hordozó izolátumban a DAG aminosav motívum - mely a levéltetúvel való átvihetôségi faktor - DVG-re változott ( 1 . ábra). Kutatók igazolták, hogy a TVMV (Tobacco vein mottling virus) DAG motívumában történt mutáció a levéltetúvel való átvitel gátlásához vezetett (Pirone és Blanc 1996, Wang et al. 1996).

A vizsgált izolátumok közti átlagos genetikai távolság 7,4\% (p-distance0.074). Ha a köpenyfehérje-gén különböző régióit vizsgáljuk, akkor elmondható, hogy az N-terminális régió (1-204nt) a legváltozékonyabb, átlagosan 12,2\% a szekvencia eltérés. Az N-terminális régió nagyfokú változékonysága jól ismert tulajdonság a potyvírusok között (Bousalem 2000, Moury 2002). A C-terminális régióban (717-915nt) 7,2\%, míg a konzervált központi régióban (205716 nt) összesen 5,2\% az átlagos szekvencia eltérés. Általánosan elmondható, hogy ezek az izolátumok szoros rokonságban állnak egymással.

\section{IRODALOM}

Andino, R.-Boddeker, N.-Gamarnik, A. V.: 1999. Intracellular determinants of picornavirus replication. Trends in Microbiol. 7: 76-82.

Bousalem, M.-Douzery, E.J. P.-Fargette, D.: 2000. High genetic diversity, distant phylogenetic relationships and intraspecies recombination events among natural populations of Yam mosaic virus: a contribution to understanding potyvirus evolution. J. Gen. Virol. 81: 243-255.

Dolja, V. V.-Haldeman, R.-Robertson, N. L.-Dougherty, W. G.-Carrington, J. C.: 1994. Distinct functions of capsid protein in assembly and movement of tobacco etch potyvirus in plants. EMBO J. 13: 1482-1491.

Gáborjányi, R.-Hoang, N. D.-Kovács, G.: 1992. Resistance of maize inbred lines and sorghum species to potyviruses found in Hungary. Cereal Res. Commun. 20: 131-137.

Gell, G.-Balázs, E.-Petrik, K.: 2010. Genetic diversity of Hungarian Maize dwarf mosaic virus isolates. Virus Genes. 40: 277-281.

Gell G.-Petrik K.-Balázs E.-Divéki Z.: 2008. Kukorica csíkos mozaik vírus (MDMV) populációk molekuláris analízise. Növényvédelem. 44. 11: 567-571.

Hajimorad, M. R.-Eggenberger, A. L.-Hill, J. H.: 2003. Evolution of Soybean mosaic virus-G7 molecularly cloned genome in Rsv1-genotype soybean results in emergence of a mutant capable of evading Rsv-1 mediated recognation. Virology. 314: 497-509.

Harrison, B. D.-Robinson, D. J.: 1988. Molecular variation in vector-borne plant viruses: epidemiological significance. Philos. Trans. R. Soc. Lond. B. Biol. Sci. 321: 447-462. 
Hoang, N. D.-Gáborjányi R.: 1991. A kukoricapatogén potyvírusok (kukorica csíkos mozaik vírus és cukornád mozaik vírus) és törzseik meghatározása cirokfajtákon és nemesítési vonalakon. Növénytermelés. 40. 4: 493-498.

Hong, Y. L.-Levay, K.-Murphy,J. F.-Klein, P. G.-Shaw, J. G-Hunt, A. G.: 1995. A potyvirus polymerase interacts with the viral coat protein and VP gin yeast-cells. Virology. 214: 159-166.

Janson, B. F.-Ellett, C. W.: 1963. A new corn disease in Ohio. Plant Dis. Rep. 47: 1107-1108.

Kong, P.-Steinbiss, H. H.: 1998. Complete nucleotide sequence and analysis of the putative polyprotein of maize dwarf mosaic virus genomic RNA. Arch. Virol. 143: 17911799.

Kovács, G.-Gáborjányi, R.-Toldi, É.: 1994. Inheritance of resistance to maize-dwarf mosaic virus and sugarcane mosaic-virus in maize. Cereal Res. Commun. 22: 361-368.

Kovács, G.-Toldi, E.-Gáborjányi, R.-Vasdinyei, R.: 1997. Effect of plant age on susceptibility of corn hybrids to maize dwaf mozaik potyvirus. Cereal Res. Commun. 25. 4: 969975.

Kovács, G.-Gáborjányi, R.-Vasdinyei, R.-Toldi, É.: 1998. Resistance of maize inbred lines to maize dwarf mosaic virus and sugarcane mosaic potyviruses. Cereal Res. Commun. 26: 195-201.

Kumar, S.-Nei, M.-Dudley, J.-Tamura, K.: 2008. MEGA: A biologist-centric software for evolutionary analysis of DNA and protein sequences. Briefings in Bioinformatics. 9. 4: 299-306.

Milinkó, I.: 1977. Some new results on maize dwarf mosaic virus in Hungary. Acta Phytopathol. Hung. 9: 329-331.

Milinkó, I.-Peti, J-Papp, I.: 1979. Problems and possibilities for control of maize dwarf mosaic virus in Hungary. Acta Phytopathol. Hung. 14: 127-131.

Moury, B.-Morel, C.-Johansen, E.-Jacquemond, M.: 2002. Evidence for diversifying selection in Potato virus Y and in the coat protein of other potyviruses. J. Gen. Virol. 83. 10: 2563-2573.

Murry, L. E.-Elliott, L. G.-Capitant, S. A.-West,J. A.-Hanson, K. K.-Scarafia, L.-Johnston, S.-Delucaflaherty, C.-Nichols, S.-Cunanan, D.-Dietrich, P. S.-Mettler, I. J.-Dewald, S.-Warnick, D. A.-Rhodes, C.-Sinibaldi, R. M.-Brunke, K. J.: 1993. Transgenic corn plants expressing MDMV strain-b coat protein are resistant to mixed infections of maize-dwarf mosaic-virus and maize chlorotic mottle virus. Bio-technology. 11: 1559-1564.

Peti J.: 1983. A kukorica csíkos mozaik vírus kártételének vizsgálata 24 kukoricahibriden. Növényvédelem. 19: 18-25.

Petrik, K.-Sebestyén, E.-Gell, G.-Balázs, E.: 2010. Natural insertions within the N-terminal region of the coat protein of Maize dwarf mosaic potyvirus (MDMV) have an effect on the RNA stability. Virus Genes. 40: 135-139.

Pirone, T. P.-Blanc, S.: 1996 Helper-dependent vector transmission of plant viruses. Ann. Rev. Phytopathology. 34: 227-247. 
Riechmann, J. L.-Laíin, S.-García, A.: 1992. Highlights and prospects of potyvirus molecular biology (review). J. Gen. Virol. 73: 1-16.

Scott, G. E.-Louie, R.: 1996. Improved resistance to maize dwarf mosaic virus by selection under greenhouse conditions. Crop Sci. 36: 1503-1506.

Seifers, D. L.-Salomon, R.-Marie-Jeanne, V.-Alliot, B.-Signoret, P.-Haber, S.-Loboda, A.Ens, W.-She, Y. M.-Standing, K. G.: 2000. Characterization of a novel potyvirus isolated from maize in Israel. Phytopathology. 90: 505-513.

Shukla, D. D.-Tosic, M.-Jilka, J.-Ford, R. E.-Toler, R. W.-Langham, M. A. C.: 1989. Taxonomy of potyviruses infecting maize, sorghum, and sugarcane in Australia and the United-States as determined by reactivities of polyclonal antibodies directed towards virus-specific N-termini of coat proteins. Phytopathology. 79: 223-229.

Simcox, K. D.-McMullen, M. D.-Louie, R.: 1995. Co-segregation of the maize-dwarf mosaic-virus resistance gene, $\mathrm{mdm} 1$, with the nucleolus organizer region in maize. Theor. Appl. Genet. 90: 341-346.

Sum I.-Sebestyén E.-Papp I.-Liszt A.: 1979. A kukorica törpe mozaik vírus hatása 15 kukoricahibridre. Növénytermelés. 28: 309-315.

Szirmai J.-Paizs L.-né: 1963. A kukorica csíkos mozaik betegsége. Növénytermelés. 12. 1: 43-50.

Szirmai, J.: 1968. The occurrence of stripe mosaic disease of maize in Hungary and possibilities of breeding for virus resistance. Acta Phytopathology Hung. 3: 189-198.

Tóbiás I.-Palkovics L.-Pereczes J.: 2003. A kukorica törpe mozaik vírus elófordulása csemegekukoricán. Növényvédelem. 39. 6: 247-250.

Tóbiás, I.-Palkovics, L.: 2004. An unusual feature at the N-terminal end of the coat protein of Maize dwarf mosaic virus isolated in Hungary. J. Phytopathology. 152: 445-447.

Toldiné Tóth É.: 2008. A vírusfertôzöttség hatása egy kukoricahibrid termésére. Növényvédelmi Tudományos Napok. Absztrakt. 18.

Toler, R. W.: 1985. Maize Dwarf Mosaic, the Most Important Virus Disease of Sorghum. Plant Dis. 69: 1011.

Tomimura, K.-Gibbs, A. J.-Jenner, C. E.-Walsh, J. A.-Ohshima, K.: 2003. The phylogeny of Turnip mosaic virus; comparisons of 38 genomic sequences reveal a Eurasian origin and a recent 'emergence' in east Asia. Mol. Ecol. 13: 2099-2111.

Urcuqui-Inchima, S.-Haenni, A. L.-Bernardi, F.: 2001. Potyvirus proteins: A wealth of functions. Virus Res. 74: 157-175.

Wang, R. Y.-Ammar, E. D.-Thornbury, D. W.-López-Moya, J.J.-Pirone, T. P.: 1996. Loss of potyvirus transmissibility and helpercomponent activity correlate with non-retention of virions in aphidstylets. J. Gen. Virol. 77: 861-867.

Williams, L. E.-Alexander, L. J.: 1965. Maize dwarf mosaic virus, a new corn disease. Phytopathology. 58: 802-804. 
A szerzők levelezési címe - Address of the authors:

Gell Gyöngyvér-Petrik Kathrin-Sebestyén Endre-Dr. Balázs Ervin MTA Mezógazdasági Kutatóintézete

Martonvásár

Brunszvik u. 2.

H-2462 